\title{
Utilization of fish waste as fish meal substitute in formulated fish diet on the growth performance of Nile tilapia fish fry (Oreochromis niloticus)
}

\author{
${ }^{1,2}$ Anizah, M.R., ${ }^{1}$ Manaf, S.R. and ${ }^{1}$ Hilaliyah, M.J.N. \\ ${ }^{1}$ Universiti Teknologi Mara, Kampus Sarawak cawangan Mukah, 96400 Mukah, Sarawak, Malaysia. \\ ${ }^{2}$ Department of Animal Science and Fishery, Universiti Putra Malaysia Bintulu Sarawak Campus, 97008 \\ Bintulu, Sarawak, Malaysia.
}

\begin{abstract}
Article history:
Received: 14 April 2021

Received in revised form: 10

May 2021

Accepted: 13 October 2021

Available Online: 26

November 2021
\end{abstract}

\section{Keywords:}

Fish meal replacement,

Fish carcass,

Oreochromis niloticus

\section{DOI:}

https://doi.org/10.26656/fr.2017.5(S4).001

\begin{abstract}
Fish meal is generally expended as the foremost protein supply in the fish diet. The rising cost of this component inflicted the aquaculture industry to seek a substitute in lessening the pellet cost. Thus, fish waste was tested in this study to investigate its viability. An experiment was performed to study the effects of fish waste and carcass on the growth performance of Nile tilapia fry. Solid fish waste of three different common species available in Mukah's wet market was formulated into an artificial diet. The diet was formulated into three treatments consist of three protein levels $(40 \%, 45 \%$ and $50 \%)$ with $4000 \mathrm{kcal} / \mathrm{kg}$ energy. A controlled group was fed with a commercial pellet consisting of $45 \%$ protein level. Fish were fed at $4 \%$ of body weight twice daily for 45 days. Fry reared in a controlled group was discovered highest weight gain, specific growth rate and length gain. There was no significant difference in all treatments for all parameters measured. The lowest weight gain and specific growth rate were recorded in fish fed $45 \%$ protein level (T2) group. Fish in T3 (50\%) achieved the highest survival rate while T1 (40\%) group recorded the lowest. The best and lowest Feed Conversion ratio (FCR) was recorded in the control group. In conclusion, the performance of formulated feed using fish waste is similar to commercial pellet as no significant difference can be observed in all parameters measured.
\end{abstract}

\section{Introduction}

Oreochromis niloticus or generally acknowledged as Nile tilapia is one of the freshwater fish species from Cichlidae family that is innate to south-western Middle East and African continent (Canonico et al., 2005; Fujimura and Okada, 2007). Apart from its distinctive taste, the Nile tilapia (Oreochromis niloticus) is an imperative commodity in the aquaculture of freshwater fish in Indonesia, but also has a great protein content to satisfy community nutrition. The high demand for Nile tilapia, however, is not adequate to rely solely on fishermen, so it desires attempt to increase its growth rate (Yunita, Sudarno, and Manan, 2019).

In many aquafeeds, fish meal is a significant conservative constituent (El-Sayed, 2004). FAO (2011) defined fish meal as a protein-rich meal resulting from processing entire fish which are typically small pelagic fish, and bycatch along with remainders, and by-products from fish processing lodges (fish offal). Although the aquaculture sector has expanded rapidly, since 1990 production of fish meal and fish oil has marginally depreciated (Tacon, 1993). Due to the ease of spoilage, Diop et al. (2013) believe abundant fish waste can establish a disposal problem and augment to the overall production cost. It is essential to turn waste into either silage or mill to resolve this problem and expend this substance in fish feed formulation.

To retain its rapid growth, the aquaculture industry ought to curtail the exploitation of fish meal in aquafeeds. The optimal requirements for protein can diverge rendering to the fish species, size, temperature, quality of water, variation in diet, and culture system formulation (Ali et al., 2008). The necessity for protein and energy is not only depending on the fish species but also subjected to the size of the fish. Abdel-Tawwab et al. (2010) also reported that the optimum growth for fry Tilapia was obtained at $45 \%$ protein diet, whereas fingerling and advanced juvenile was obtained at $35 \%$ protein diet.

Fish gain and metabolize protein highly to be 
expended as energy from dietary (Aladetohun and Sogbesan, 2013). Attribute of fish meal possessing high protein, and equalized essential amino acid profile has made the production of commercial aqua-foods dependent on this ultimate source (Tacon, 1993; Watanabe, 2002; El-sayed and Gaber, 2004). Fish meal is essentially can be interchanged with other forms of protein. An optimal balance of essential amino acids must therefore be preserved. Moreover, priority must be given to intensify the supply of nutrients and maximize the digestible protein to the energy balance of the alternate diets (Ogello et al., 2014).

The amount of crude protein in fish feed has important impacts on fish's physiological functions. Given that fishmeal processing has both economic and ecological costs, the fish feed industry is at a turning point from fishmeal to alternative sources of protein (Kasthuriarachchi and Hettiarachchi, 2011). The survival and development of fish are closely linked to the nature of the feed distributed and, in particular, the source of protein (Diop et al., 2013). Thus, objective of this research is to determine growth performance of Nile tilapia using fish waste substituting fish meal in dietary.

\section{Materials and methods}

\subsection{Sample collection}

Fish waste represented as raw material was collected from wholesalers in Mukah wet market. Sample collected were Pomfret spp. (Pomfret fish), Dasyatis spp. (Stingray fish) and Euthynnus affinis (Skipjack tuna fish). These are major species or collection of species widely available in the local wet market. The fish waste samples were sorted in the lab, whereby the fish gut was removed and excluded from the experiment to avoid fish gut microbiome from affecting the data. Solid fish waste consists of head, bones, skin, tails, scales and frames.

\subsection{Development of fish pellet}

Material drying and crushing were performed in aquatic laboratory UiTM Sarawak Mukah Campus. The samples were completely dried using $180^{\circ} \mathrm{C}$ until constant dry weight was achieved. The moisture was $9.84 \%$. The samples were then ground into fine powder using a Grinder Powder Machine.

The proximate analysis on the fish waste powder was done in Malaysian Agricultural Research and Development Institute (MARDI) Serdang. Proximate analysis was carried out on the powdered material in order to profile the protein, energy ( $\mathrm{kcal} / \mathrm{kg}$ ), lipid, fibre, and ash contents. The same process was applied on rice bran, corn meal, fish oil, and wheat gluten in order to allow accurate calculation of pellet nutritional content. Fish pellet was formulated using 3 protein levels (40\%, $45 \%$ and $50 \%$ ) with $4000 \mathrm{kcal} / \mathrm{kg}$ energy (El Sayed and Teshima, 1992).

The data from the proximate analysis was fed into WinFeed version 2.8 software to determine the optimized amount of each ingredient for pellet preparation. The treatments' composition and proximate composition was shown in Table 1, Table 2 and Table 3. The ingredients were mixed accordingly using a mixer (Panasonic MK-GB3WSK 5-Speed Stand Mixer) to get a homogenous mixture. Agar was mixed together with the mixture as a binding agent. Water was steadily added to each treatment while mixing the ingredients to get a compact and sticky formulation. The mixture was thoroughly kneaded to form dough. Then the dough was divided into a number of pieces. Each piece was strolled and inserted into a noodle maker machine (KENT 16009, single phase $220-240 \mathrm{~V}$ ). The pellets were then cut into small pieces, dried in the oven at $60^{\circ} \mathrm{C}$ for an overnight (9\% moisture). After 24 hours, the pellet was taken out and fish oil was applied onto the pellet. Then the pellet

Table 1. Number of treatment and replication

\begin{tabular}{|c|c|c|c|c|}
\hline $\begin{array}{l}\text { Control (commercial } \\
\text { pellet, } 45 \% \text { protein) }\end{array}$ & $\begin{array}{c}\mathrm{T} 1 \\
\text { Protein: Energy } \\
40 \%: 4000 \mathrm{kcal} / \mathrm{kg}\end{array}$ & \multicolumn{2}{|c|}{$\begin{array}{c}\mathrm{T} 2 \\
\text { Protein: Energy } \\
45 \%: 4000 \mathrm{kcal} / \mathrm{kg}\end{array}$} & $\begin{array}{c}\mathrm{T} 3 \\
\text { Protein: En } \\
50 \%: 4000 \mathrm{k}\end{array}$ \\
\hline 3 aquaria & 3 aquaria & \multicolumn{2}{|c|}{3 aquaria } & 3 aquari \\
\hline \multicolumn{5}{|c|}{ Table 2. Composition (\%) of experimental diets } \\
\hline \multicolumn{2}{|l|}{ Ingredients } & $\mathrm{T} 1$ & $\mathrm{~T} 2$ & T3 \\
\hline \multicolumn{2}{|c|}{ Fish waste (Fish Meal) } & 31.69 & 47.63 & 77.94 \\
\hline \multicolumn{2}{|c|}{ Vitamin mineral premix ${ }^{a}$} & 1 & 1 & 1 \\
\hline \multicolumn{2}{|c|}{ Wheat gluten } & 26.22 & 21.62 & 1.6 \\
\hline \multicolumn{2}{|l|}{ Corn meal } & 12.02 & 7.68 & 0 \\
\hline \multicolumn{2}{|c|}{ Sago meal (Tapioca) } & 8.32 & 16.07 & 13.46 \\
\hline \multicolumn{2}{|c|}{ Rice bran } & 14.76 & 0 & 0 \\
\hline \multicolumn{2}{|l|}{ Fish oil } & 1 & 1 & 1 \\
\hline \multicolumn{2}{|l|}{ Agar } & 5 & 5 & 5 \\
\hline
\end{tabular}

${ }^{a}$ Consists (mg/kg or IU/kg): Vit. A, 2.200.000 IU. Vit. D3, 1100.000 IU. Vit. E, 1.500 I.U. Vit. K 800 mg. Vit. B1 1100 mg. Vit. B2 $200 \mathrm{mg}$. Vit. B6 $2.000 \mathrm{mg}$ 
Table 3. Proximate composition (\%) of feed ingredients

\begin{tabular}{lcccccc}
\hline Ingredients & Gross Energy (cal/g) & Crude protein & Crude fat & Crude fiber & Ash & Moisture \\
\hline Fish waste (Fish Meal) & 4842.91 & 69.26 & 18.32 & 0.24 & 11.65 & 9.84 \\
Wheat gluten & 5201 & 71 & 6 & 0 & 1 & 7 \\
Corn meal & 3984.95 & 9.6 & 3.8 & 2.6 & 1.3 & 11 \\
Sago meal (Tapioca) & 3603.25 & 2.3 & 0.7 & 4.6 & 2.9 & 12 \\
Rice bran & 4211.7 & 12.7 & 13.7 & 11.6 & 11.6 & 9 \\
Fish oil & 9355.5 & 0 & 99 & 0 & 0 & 0 \\
\hline
\end{tabular}

was cooled at room temperature. Once the pellet has 2.4 Analysis of growth

cooled, the pellet was packed in a labelled container.

Research design was a completely randomized design (CRD), one factorial experiment. Each 3 treatments and 1 control have triplicated. After the adaptation period, 120 fish were distributed into $45 \mathrm{~L}$ tank (10 fish per tank).

\subsection{Feeding trial of Oreochromis niloticus}

Feeding trial was accomplished in the Aquaculture Laboratory, Faculty of Plantation, University Technology MARA, Mukah. Fry of Oreochromis niloticus $(2.24 \pm 0.08 \mathrm{~g})$ were kept in $1 \mathrm{~m}^{3}$ tank containing aerated recirculating freshwater. The fry was conditioned for one week before the feeding trial begin in the aquaria. They were fed with commercial pellet $(45 \%$ protein) along the week.

After acclimatization, fish $(2.52 \pm 0.03 \mathrm{~g})$ were divided into aquaria accordingly (Table 1). Fish were given commercial fish pellet (45\% protein) as control. Formulated fish diet was given to the fish accordingly to the labelled treatment. Each treatment was replicated thrice. Growth of fish was recorded and monitored for 45 days.

During the study, water quality parameters were measured daily and adjusted to the water temperature, $\mathrm{pH}$ and dissolved oxygen were maintained at $28.8 \pm 0.1^{\circ}$ $\mathrm{C}, \mathrm{pH} 7.4 \pm 0.2$, and dissolved oxygen $8.10 \pm 0.2 \mathrm{mg} / \mathrm{L}$, respectively (Sonmez et al., 2015). To measure the dissolved oxygen and temperature, a portable dissolve oxygen (DO) meter was utilized. Multiparameter Ion Analyzer (HANNA Instruments) and pH-meter were used to measure the concentration of unionized ammonia $\left(\mathrm{NH}_{3}\right)$ and $\mathrm{pH}$ level respectively. Approximately $40 \%$ of the water was replenished with new water daily to sustain good water quality. Fish mortality was recorded on a daily basis.

The 4\% from Orechromis niloticus fry body weight (Terpstra, 2015) was utilized as the feeding rate for the fish in two feeding times for 45 days. Sampling on the fish growth rates, mortalities was done every four days intervals. This new data was utilized to adjust the new feeding rations. All fish were fasted 24 hours prior to weighing and sampling.
Before completing the feeding trial, fish were weighted to record and determine the final weight (FW), weight gain (WG), specific growth rate (SGR), feed conversion ratio (FCR), protein efficiency ratio (PER), and survival rate (\%). Calculations were conducted using the following formula (Abedian et al., 2017):

Weight gain (WG) $(\mathrm{g})=$ Final weight $(\mathrm{g})$ - Initial weight (g)

Length gain $(\mathrm{LG})(\mathrm{cm})=$ Final length $(\mathrm{cm})-$ Initial length $(\mathrm{cm})$

Specific growth rate $(\mathrm{SGR})(\% /$ day $)=($ \ln final mean weight $(\mathrm{g})-\ln$ initial mean weight $(\mathrm{g}) \rrbracket /(45$ days $) \times 100$ Feed conversion ratio $(\mathrm{FGR})=($ feed intake $(\mathrm{g})) /($ weight gain $(\mathrm{g}))$

Survival rate $(\%)=($ final number of fish - initial number of fish $) \times 100$

Protein efficiency ratio $($ PER) $=$ Weight gain per fish (g) / Protein intake per fish (g)

\subsection{Statistical analysis}

Data were analyzed using one-way analysis of variance (ANOVA) of the Statistical Package for Social Sciences (SPSS) program version 25 (SPSS Inc., Chicago, IL, USA). All data were presented as mean \pm standard error; S.E. Differences among the treatments were tested at $\mathrm{P} \leq 0.05$ using Tukey's tests respectively (Zar, 1996).

\section{Results}

The growth characteristics of fish fed the the different protein levels using fish waste were presented in Table 4. Computation of Final Mean Weight [A], Weight Gain [B], Length Gain[C], Specific Growth Rate $[D] \pm$ S.E.M (standard error of mean) in bar chart was depicted in Figure 1. A bar graph of fish Survival Rate (SR) \pm S.E.M (standard error of mean) in bar chart can be referred in Figure 2.

The data represented in Table 4 revealed that there were no significant differences in all treatments in all parameters measured. Weight gain was highest for fish fed commercial pellet containing $45 \%$ protein level 
Table 4. Growth parameters of Nile tilapia fry (Oreochromis niloticus) fed diets containing three concentration levels of protein with commercial pellet (control) for 45 days.

\begin{tabular}{lcccc}
\hline \multirow{2}{*}{ Parameters } & \multicolumn{4}{c}{ Diets } \\
\cline { 2 - 5 } & Control & Treatment 1 & Treatment 2 & Treatment 3 \\
\hline FMW $(\mathrm{g})$ & $7.08 \pm 0.55$ & $4.94 \pm 0.66$ & $4.90 \pm 0.64$ & $5.81 \pm 0.39$ \\
FML $(\mathrm{cm})$ & $7.57 \pm 0.32$ & $6.41 \pm 0.22$ & $6.73 \pm 0.48$ & $7.25 \pm 0.13$ \\
TWG $(\mathrm{g})$ & $4.56 \pm 0.55$ & $2.42 \pm 0.66$ & $2.38 \pm 0.64$ & $3.29 \pm 0.39$ \\
TLG $(\mathrm{cm})$ & $2.18 \pm 0.32$ & $1.02 \pm 0.22$ & $1.34 \pm 0.48$ & $1.86 \pm 0.19$ \\
SGR (\%/day) & $10.12 \pm 1.22$ & $5.38 \pm 1.47$ & $5.29 \pm 1.43$ & $7.31 \pm 0.86$ \\
SR (\%) & $53.33 \pm 12.02$ & $43.33 \pm 3.33$ & $60.00 \pm 5.77$ & $63.33 \pm 8.82$ \\
FCR & $1.78 \pm 0.10$ & $2.85 \pm 0.65$ & $2.76 \pm 0.45$ & $2.12 \pm 0.16$ \\
PER & $*$ & $0.06 \pm 0.02$ & $0.05 \pm 0.01$ & $0.07 \pm 0.01$ \\
\hline
\end{tabular}

Values are presented as mean \pm standard error. Values with different superscripts in the same row are significantly different $(\mathrm{P}<0.05)$.

FMW: Final mean weight, FML: Final mean length, TWG: Total Weight gain, TLG: Total Length gain (TLG), SGR: Specific Growth rate, SR: Survival rate, FCR: Feed Conversion ratio, PER: Protein Efficiency Ratio.

*Control was fed with commercial pellet, so it was not counted for Protein Efficiency Ratio
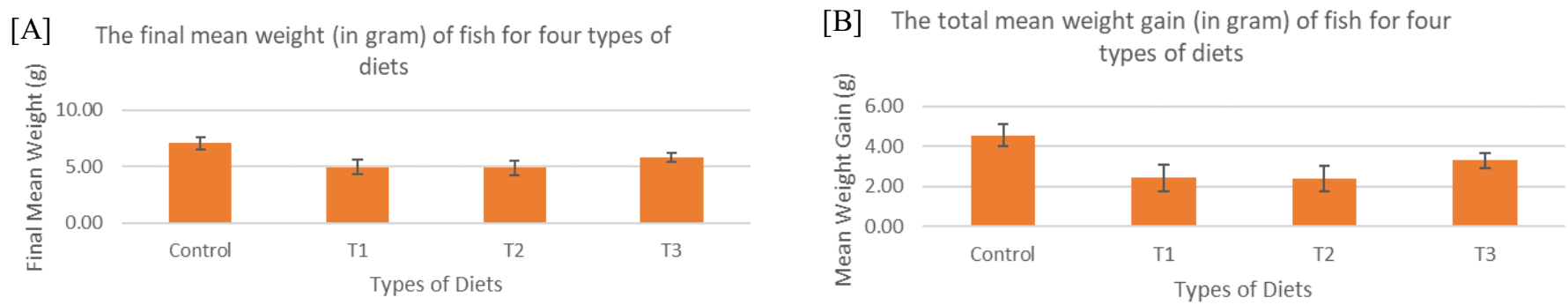

[C] The total mean length gain (in centimeter) of fish for four types of diets

[D] The specific growth rate (in\% per day) of fish for four types of diets
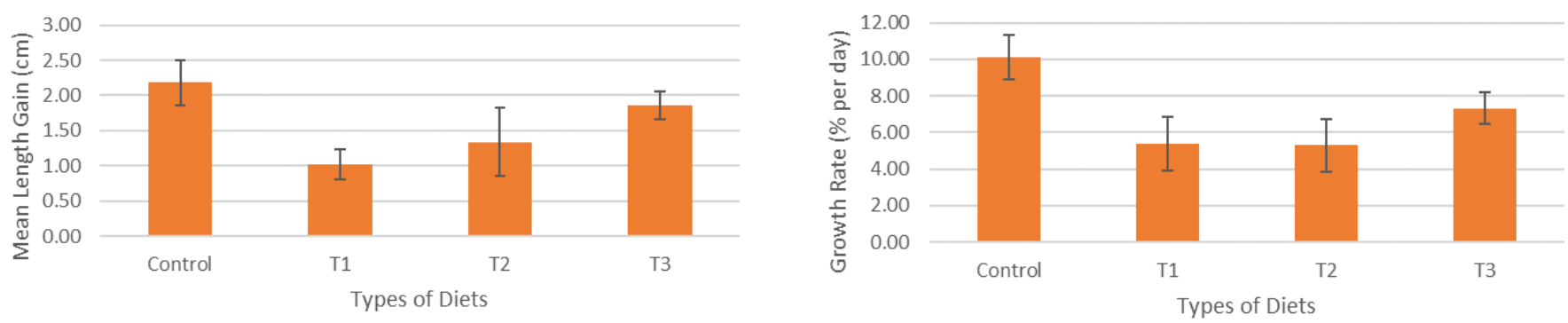

Figure 1. Computation of Final Mean Weight [A], Weight Gain [B], Length Gain[C], Specific Growth Rate [D] \pm S.E.M in bar chart

The Mean of Fish Survival Rate (in percentage) for Four Types of Diets

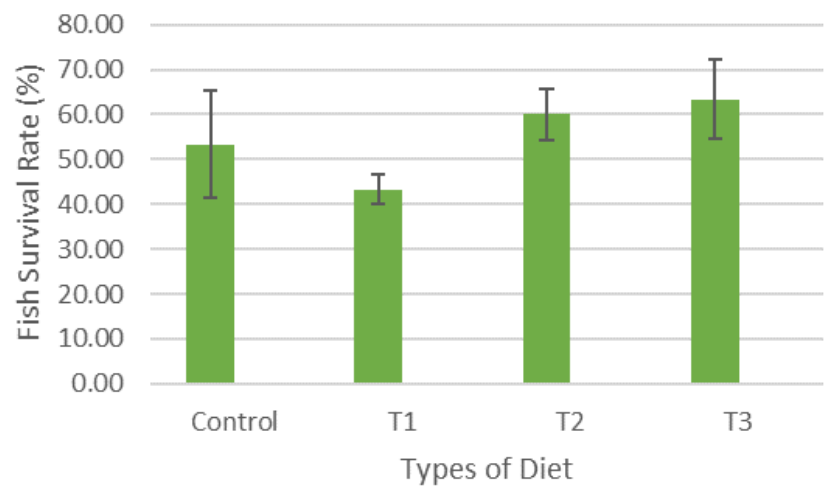

Figure 2. A bar graph of fish Survival Rate (SR) \pm S.E.M in bar chart

$(4.56 \pm 0.55 \mathrm{~g})$. The lowest weight gain was verified in $\mathrm{T} 2$ group which was applied with $45 \%$ of protein of formulated feed $(2.38 \pm 0.64 \mathrm{~g})$. Between all treatments, the fish fry fed diet control containing $45 \%$ protein level of commercial pellet had the highest specific growth rate $(10.12 \pm 1.22 \%$ /day $)$ and highest length gain $(2.18 \pm 0.32$ $\mathrm{cm})$. Opposite result showed in fry fed T2 diet containing $45 \%$ of protein level in formulated feed which had the lowest specific growth rate $(5.29 \pm 1.43 \% /$ day $)$. The lowest length gain was discovered in fish fed diet T1 containing $40 \%$ protein level in formulated feed $(1.02 \pm 0.22 \mathrm{~cm})$.

Among treatment groups fed with formulated feed using fish waste, treatment 3 containing $50 \%$ protein recorded the best growth in term of weight gain $(3.29 \pm 0.39 \mathrm{~g})$, specific growth rate $(63.33 \pm 8.82 \% /$ day $)$, feed conversion ratio $(2.12 \pm 0.16)$ and protein efficiency ratio $(0.07 \pm 0.01)$. The poorest performance among fish fed formulated feed groups was achieved by treatment 2 
containing $45 \%$ protein with weight gain $(2.38 \pm 0.64 \mathrm{~g})$, specific growth rate $(5.29 \pm 1.43 \% /$ day $)$ and feed conversion ratio $(2.76 \pm 0.45)$. Nonetheless there was no significant differences among all groups in all parameters measured.

It can even be spotted that there were no significant differences $(\mathrm{P}<0.05)$ in fry weight gain, feed conversion ratio (FCR), survival, specific growth rate (SGR) and length gain. The feed conversion ratio (FCR) ranged from 1.78 to 2.85 for all treatments groups. The higher value of FCR $(2.85 \pm 0.65)$ was recorded in fry fed T1 diet comprising $40 \%$ protein level in formulated diet. Commercial pellet consisting $45 \%$ protein level which was fed to control group gained the lowest FCR $(1.78 \pm 0.10)$ but it had not been significantly different with other diets. Furthermore, the survival rate reached by T3 was the highest $(63.33 \pm 8.82 \%)$ but it was not significantly different with the rest. In contrary, fry fed diet containing $40 \%$ protein level in $\mathrm{T} 1$ recorded the lowest survival rate $(53.33 \pm 12.02 \%)$ and yet did not show significant difference with other treatments.

From the results, mean survival rate for all treatments, including control group, ranged from $43 \%$ to $63 \%$. High mortality result was recorded in T1 diet, which cause the survival rate to be the lowest among others. In contrast, the survival rate of fish in T3 diet was found to be the highest during a 45-day experimental period. Thus, different level of protein in fish diet does affect the survival rate of Nile tilapia fry.

\section{Discussion}

\subsection{Waste meals application}

This study was intended to assess the possibility of replacing fish meal in a standard commercial tilapia diet with common fish waste present in the wet market of Mukah. There were no significant differences in all parameters measured. This is similar to Arruda et al. (2009) who did an experiment on fish silage performance analyzed on Black Bass (Micropterus salmoides). Zerai et al. (2008) discerned that brewer's waste can effectively replace a standard commercial feed up to $50 \%$ of the fish meal protein, with no adverse effect on tilapia development. Diop et al. (2013) learnt that shrimp waste meals are essential tilapia feedstuffs, and up to $45 \%$ of steamed shrimp waste meals can be exploited in tilapia diets. The inclusion of up to $50 \%$ tuna silage hydrolysates replacing a soybean meal diet had a positive impact on Nile tilapia fry feed consumption as well as growth and feed utilisation. This suggesting that the percentage could react equivalent to the fish fed with regular commercial feed (Hernandez et al., 2013).

\subsection{Utilization of fish silage}

Abdallah et al. (2018) uncovered that the best mixing ratio of fish waste with rice bran was $3.35: 1$, providing $62.3 \%$ moisture content in silage production. Haider et al. (2016) proposed that fish silage, if carefully handled and appropriately processed, can be a low-cost and more steadfast substitute to fish meal in fish feed. This is because fish silage is formulated from viscera of the fish waste body, and is not used in the raw form of animal feed. In Labeo rohita fingerling, feed encompassing $75 \%$ acid silage exhibited better growth compared to its counterparts. Fish meal, on the other hand, is a substantial and costly constituent used in livestock and fish feed. The use of fish meal is on the increase, while its usage is on the decline, and its price is steadily rising. Future research could employ fish silage to supplant the role of fish meal in aquaculture dietary nutrition to shrink high costs. In addition, the production of fish silage is uncomplicated, and entails comparatively less inputs as opposed to the production of fish meal.

\subsection{Utilization of by-products}

Peralta et al. (2016) evaluated a by-product of processing oysters (Crassostrea iridalei) as a potential source of protein to replace fish meal in the Nile tilapia diet for human consumption. In their conclusion, in the diet of Nile tilapia fry, oyster by product could substitute as much as $63.8 \%$ by weight of dietary fish meal and potentially a significant proportion of the mineral mix. Yunita, Sudarno, and Manan (2019) did a study to verify the effect of the appendage of shrimp waste, and coconut pulp to recuperate protein retention, energy retention in Nile tilapia (Oreochromis niloticus) growth rate. Based on the results, it can be disclosed that the addition of $30 \%$ shrimp waste and coconut pulp flour to the commercial Nile tilapia feed (Oreochromis niloticus) significantly affected the $12.05 \%$ energy retention value, $21.25 \%$ protein retention and $1.47 \%$ growth rate. The growth rate of Nile tilapia can be progressed by adding organic waste to commercial fish feed. Contrary to this finding discovered in this study, fish waste could completely replace fishmeal role in commercial pellet by giving non-significant differences in Nile tilapia growth performance.

\subsection{Cost effectiveness}

Khan, Siddique, and Zamal (2013) experimented the nutritional aptness and cost-effectiveness of rice polish and mustard oil cake as protein supplies in the Nile tilapia (Oreochromis niloticus) diet. Growth output appeared to decrease in contrast with an increase in rice polish and mustard oil cake inclusion rate. Without any major change in growth efficiency, partial replacement 
of fish meal with rice polish and mustard oil cake would be cost effective. Compared to this study, although the findings indicate no significant difference between the control and treatment groups in terms of fish performance growth, further research should be carried out to compare the cost of commercial pellets and formulated diets in order to ascertain the cost effectiveness. This is similar to a study done by Salem et al. (2008) in ascertaining the effect of replacing fish meal with silkworm, Bombyx mori pupae meal (SWPM), as a non-conventional source of protein, on Nile tilapia fingerlings fish. Insignificant $(\mathrm{P}>0.05)$ differences were discerned between fish fed diets containing $33.33 \%$ or $66.66 \%$ of silkworm, Bombyx mori pupae meal and control diets (fish meal) in the growth performance, and protein utilization. This is in agreement with this study as the performance of formulated diet and control diet has no significant difference. Salem et al. (2008) concluded that diets containing silkworm, Bombyx mori pupae meal of $66.66 \%$ were economically superior to the other diets examined. Compared with control diets, it reduced approximately $18.79 \%$ of feeding costs per fish unit.

\subsection{Feed utilization, and acceptance}

According to Hernandez et al. (2013), low palatability decreases feed consumption, thus decreasing the quantity of usable nutrients for the growth of fish. The poor acceptance of formulated feed diets in this study is therefore the most recognisable cause of decreased growth, while the high uptake of the control diet, which could be accredited to the high palatability of its constituents, as well as essential amino acids, vitamins and minerals content, could serve to rationalize the fact that the fish consumed this diet attained the highest gain weight. Nevertheless, in both groups, there was no significant difference in their growth performance. The results of weight gain in treatment groups is lower than control group. The better outcome achieved may be due to diets that were developed on the basis of the ideal principle of protein. Instead of the crude protein used in this analysis, this term relates to the basic prerequisites of essential amino acids for ideal fish growth, which only took into account the protein content and, consequently, may present amino acid imbalances and, consequently low growth and feed quality (Arruda et al., 2009). The irregularity in the results analysed in this study due to the need to deliberate during dietary formulation on the quantitative and qualitative requirements for the species and it's growth stage.

\subsection{Amino acid limitation}

Poultry by-product meal (PBM), feather meal (FeM), blood meal (BM), and meat and bone meal (MBM) are the major land-dwelling by-product meals which have been investigated as fish meal replacements for tilapia. Regardless of their relatively great crude protein content, they are typically undersupplied in one or more essential amino acids, whereby lysine, methionine and isoleucine are usually the limiting essential amino acids (Tacon and Jackson, 1985). However, by combining complementary protein by-product meals in order to achieve the optimal essential amino acids profile, these imbalances can be resolved (Davies et al., 1989). Attributes of animal proteins which are deficient in anti-nutritional factors, appetising, lower cost and more straightaway available than fish meal, rendering these proteins as ideal fish meal substitutes (El-Sayed, 1999). Djissou, Adjahouinou, and Koshio (2016) discovered the best growth in Clarias gariepinus fingerlings consuming diet encompassing the highest earthworm/maggot ratio (2:5) to suit the protein and amino acid requirements. Deficient of amino acids in fish feed will not meet the animal needs perfectly, while nitrogenized catabolism increment will pollute the aquatic environment, reduction in the proteinic retention, and consequently diminish the fish growth (Medale and Kaushik, 2009). Decrement of growth in T2 group in this study might be attributed of certain amino acid limitation present in the formulated diet.

\subsection{Other possible fish meal substitutes}

The purpose of research done by Soltan and Samra (2010) was to study the impact on the diets of Nile Tilapia (Orechromis niloticus) fingerlings of introducing increasing levels of fermented fish silage as a substitute for fish meal. Control group fed on $100 \%$ fermented fish silage, the highest average body weight, $(40.14 \mathrm{~g})$, was reported, followed by those fed with the diet containing $75 \%$ fermented fish silage (39.35 g), and the difference between these two groups was not significant. The fish growth declined following the elevated amount of silage applied in the diets. The best overall growth response obtained in Nyina-Wamwiza et al. (2010) study was a juvenile African catfish (Clarias gariepinus) fed diet containing $25 \%$ fish meal when sunflower oil cake inclusion was reduced to $25 \%$. Poor performance of fish fed formulated feed in this sudy might require replacement of fish waste in future study. The most relevant choice may be the use of terrestrial animal meals and plant protein-rich derivatives, and the optimum use of fish resources (trash fish) and the utilisation of under-used ocean resources such as Antarctic krill (Tacon and Metian, 2008). Other protein sources such as single cell proteins, earthworms, insects, snails, maggots, and frogs have also been suggested by experts as possible fish meal replacers. Their sustainable production and productive use in aquaculture, however, require further economic scrutiny. 
Feed conversion ratio (FCR) in this study ranged from 1.78 to 2.85 . The best FCR was attained by fish in control group fed commercial pellet. This is different with Haider et al. (2016) who discovered that in comparison with other diets, the FCR values $(1.98 \pm 0.44)$ reported in their analysis for the feed comprising $75 \%$ fish silage was more economical. The presence of relatively higher amounts of free amino acids and active hydrolytic enzymes can lead to a better growth rate of fish fed with $75 \%$ acid silage. Kasthuriarachchi and Hettiarachchi (2011) did a study to explore whether the integrated fish feed from chicken blood meal could contribute well to growth success and protein assimilation in red tilapia while reducing feed production costs. For the experimental feed and control feed, the respective feed conversion ratios (FCR) observed were $1.45 \pm 0.08$ and $1.34 \pm 0.24$, which were not significantly different from each other similar to the finding discerned in this study. Ezymatic action in diet preparation elevate digestible protein availability resulted in greater growth performance in fish (Kamson et al., 2018). FCR values in experimental diets in this study were smaller than the values recorded by Ali and Salim (2004); 5.27 FCR for rice polish and $3.02 \mathrm{FCR}$ for fish meal; conversely, Jabeen, Salim, and Akhtar (2004) testified comparable values for cotton seed meal diets. The factors contributing to this difference due to dissimilar fish species and unalike feed type.

In conclusion, from the findings obtained, fish waste consisting major species in Mukah's wet market could replace fish meal in Nile Tilapia (Orecochromis niloticus) fry diet by giving non-significant differences in all parameters measured. According to Michael, David and Carole (1994), it is an urgency on the essential for auxiliary study on the prospective replacement for both fish meal and fish oil totally or partially. The studies should cover consequence on other factors embracing immune function and disease resistance.

\section{Acknowledgement}

The research work was funded by UiTM Sarawak Campus, Dana Kecemerlangan (Grant no. 600-UiTMKS (RMU.5/2/KCMT)(08/2019).

\section{References}

Abdallah, S.E., Elmessery, W.M., Abdelrahman, M.M. and Abdelglil, A.A. (2018). Efficiency enhancement of silage making from fish wastes. Misr Journal of Agricultural Engineering, 35(3), 1039-1060. https:// doi.org/10.21608/mjae.2018.95598

Abdel-Tawwab, M., Ahmad, M., Khattab, Y. and Shalaby, A. (2010). Effect of dietary protein level, initial body weight, and their interaction on the growth, feed utilization, and physiological alterations of Nile tilapia, Oreochromis niloticus (L.). Aquaculture, 298(3-4), 267-274. https:// doi.org/10.1016/j.aquaculture.2009.10.027

Abedian, A., Azari, T., Afsharnasab, M. and Razavilar, V. (2017). The comparative effects of dietary supplementation with Pediococcus acidilactiti and Enterococcus faecium on feed utilization, various helath-related characteristics and yersiniosis in rainbow trout (Oncorhynchus mykiss Walbaum, 1792). Iranian Journal of Fisheries Sciences, 16(2), 753-773.

Aladetohun, N. and Sogbesan, O. (2013). Utilization of blood meal as a protein ingredient from animal waste product in the diet of Oreochromis niloticus. International Journal of Fisheries and Aquaculture, 5(9), 234-237.

Ali, A., Al-Ogaily, S., Al-Asgah, N., Goddard, J. and Ahmed, S. (2008). Effect of feeding different protein to energy $(\mathrm{P} / \mathrm{E})$ ratios on the growth performance and body composition of Oreochromis niloticus fingerlings. Journal of Applied Ichthyology, 24(1), 31-37.

Ali, T. and Salim, M. (2004). Studies on the growth response and feed conversion ratio (FCR) of Labeo rohita fingerlings fed on rice polish, fish meal and sunflower meal. International Journal of Agriculture and Biology, 6, 914-917.

Arruda, L.F., Borghesi, R., Portz, L., Cyrino, J.E. and Oetterer, M. (2009). Fish silage in black bass (Micropterus salmoides) feed as an alternative to fish meal. Brazilian Archives of Biology and Technology, 52(5), 1261-1266. https://doi.org/10.1590/S151689132009000500025

Canonico, G., Arthington, A., McCrary, J. and Thieme, M. (2005). The effects of introduced tilapias on native biodiversity. Aquatic Conservation: Marine and Freshwater Ecosystems, 15(5), 463-483. https:// doi.org/10.1002/aqc.699

Davies, S., Williamson, J., Robinson, M. and Bateson, R. (1989). Practical inclusion levels of common and by products on complete diets for tilapia (Oreochromis mossambicus), presented at Proceedings of the Third International Symposium on Feeding and Nutrition in Fish, p. 325-332. Toba, Japan.

Diop, D., Fall, J., Sagne, M., Loum, A., Ndong, D., Diouf, M., Sarr, A., Ayessour, N. and Thiaw, O.T. (2013). Use of Biochemically Improved Shrimp Industry Wastein Fry Tilapia (Oreochromis niloticus, Linnaeus 1758) Diets: Effects on Growth Performance and Carcass Composition. Journal of Biology and Life Science, 4(2), 328-340. https:// 
doi.org/10.5296/jbls.v4i2.4091

Djissou, A., Adjahouinou, D. and Koshio, S. (2016). Complete replacement of fish meal by other animal protein sources on growth performance of Clarias gariepinus fingerlings. International Aquatic Research, 8, 333-341. https://doi.org/10.1007/ s40071-016-0146-x

El-Sayed, A. (1999). Alternative dietary protein sources for farmed tilapia, Oreochromis spp. Aquaculture, 179(1-4), 149-168. https://doi.org/10.1016/S00448486(99)00159-3

El-Sayed, A. (2004). Protein nutrition of farmed tilapia: searching for unconventional sources, presented at Proceedings of the Sixth International, New dimensions in farmed tilapia. Retreived from website: https://cals.arizona.edu/azaqua/ista/ista6/ ista6web/pdf/364.pdf

El-Sayed, A. and Gaber, M. (2004). Use of cottonseed meal supplemented with iron for detoxication of gossypol as a total replacement of fishmeal in Nile tilapia, Oreochromis niloticus (L) diets. Aquaculture Research, 34(13), 1119-1127.

El-Sayed, A. and Teshima, S. (1992). Protein and energy requirements of Nile tilapia, Oreochromis niloticus, fry. Aquaculture, 103(1), 55-63. https:// doi.org/10.1016/0044-8486(92)90278-S

FAO. (2011). Aquaculture development, Use of wild fish as feed in aquaculture. FAO Technical Guidelines for Responsible Fisheries. Rome: FAO.

Fujimura, K. and Okada, N. (2007). Development of the embryo, larva and early juvenile of nile tilapia Oreochromis niloticus (Pisces: Cichlidae). Developmental staging system. Development, growth and differentiation, 49(4), 301-324. https:// doi.org/10.1111/j.1440-169X.2007.00926.X

Haider, M.S., Ashraf, M., Azmat, H., Khalique, A., Javid, A., Atique, U. and Akram, S. (2016). Nutritive evaluation of fish acid silage in Labeo rohita fingerlings feed. Journal of Applied Animal Research, 44(1), 158-164. https:// doi.org/10.1080/09712119.2015.1021811

Hernandez, C., Olvera-Novoa, M., Voltolina, D., Hardy, R., Gonzalez-Rodriguez, B., Dominguez-Jimenez, P. and Agramon-Romero, S. (2013). Use of tuna industry waste in diets for nile tilapia, Oreochromis niloticus, fingerlings: effect on digestibility and growth performance. Latin American Journal of Aquatic Research, 41(3), 468-478. https:// doi.org/10.3856/vol41-issue3-fulltext-10

Jabeen, S., Salim, M. and Akhtar, P. (2004). Study on feed conversion ratio of major carp Cirrhinus mrigala fingerlings fed on cotton seed meal, fishmeal and barley. Pakistan Veterinary Journal, 24, 42-46.

Kamson, Makamguang, Sahu, Brundaban, Raman, Sudhanshu. and Dorothy. (2018). Use of fish silage based blended protein source for replacement of fish meal in thai-pangas diet. International Journal of Current Microbiology and Applied Sciences, 7(10), 2949-2961.

https://doi.org/10.20546/ ijcmas.2018.710.342

Kasthuriarachchi, T. and Hettiarachchi, M. (2011). Effects of chicken blood meal incorporated fish feed, on growth performances and protein assimilation in red tilapia, presented at Proceedings of the Seventeenth Sessions of the Sri Lanka Association for Fisheries and Aquatic Resources. Colombo, Sri Lanka.

Khan, M., Siddique, M. and Zamal, H. (2013). Replacement of fish meal by plant protein sources in Nile tilapia (Oreochromis niloticus) diet: growth performance and utilization. Iranian Journal of Fisheries Sciences, 12(4), 855-863.

Medale, F. and Kaushik, S. (2009). Sources of protein in feed for farmed fish. Cahiers Agricultures, 18, 103111. https://doi.org/10.1684/agr.2009.0279

Michael, A., David, A. and Carole, J. (1994). Evaluation of artificial diets for cultured fish. Northeastern Regional Aquaculture Center Fact Sheet, 222, 1-4.

Nyina-Wamwiza, L., Wathelet, B., Richir, J., Rollin, X. and Kestemont, P. (2010). Partial or total replacement of fish meal by local agricultural byproducts in diets of juvenile African catfish (Clarias gariepinus): growth performance, feed efficiency and digestibility. Aquaculture Nutrition, 16(3), 237247. https://doi.org/10.1111/j.13652095.2009.00658.x

Ogello, E.O., Munguti, J.M., Sakakura, Y. and Hagiwara, A. (2014). Complete replacement of fish meal in the diet of nile tilapia (Oreochromis niloticus L.) grow-out with alternative protein sources. A review. International Journal of Advanced Research, 2(8), 962-978.

Peralta, E.M., Tumbokon, B.M. and Serrano, Jr., A.E. (2016). Use of oyster processing byproduct to replace fish meal and minerals in the diet of nile tilapia Oreochromis niloticus fry. The Israeli Journal of Aquaculture, 2016, 1329-1335. https:// doi.org/10.46989/001c.20792

Salem, M., Khalafalla, M., Saad, I. and El-Hais, A. (2008). Replacement of fish meal by silkworm bombyx mori pupae meal, in nile tilapia, Oreochromis niloticus diets. Egyptian Journal of Nutrition and Feeds, 11(3), 611-624. 
Soltan, M. and Samra, I. (2010). Partial or complete replacement of fish meal by fermented fish byproducts in the diets of nile tilapia (Oreochromis niloticus) fingerlings. Abbassa International Journal of Aquatic Science. Special Issue (The Third Scientific Conference, Al Azhar University, Cairo, 17-18 October 2010), p. 1-19. Al Azhar University: Cairo, Egypt.

Sonmez, A.Y., Bilen, S., Albayrak, M., Yilmaz, S., Biswas, G., Hisar, O. and Yanik, T. (2015). Effects of dietary supplementation of herbal oils containing 1,8-cineole, carvacrol or pulegone on growth performance, survival, fatty acid composition, and liver and kidney histology of rainbow trout (Oncorhyncus mykiss) fingerlings. Turkish Journal of Fisheries and Aquatic Sciences, 15, 813-819. https://doi.org/10.4194/1303-2712-v15_4_04

Tacon, A. (1993). Feed ingredients for warm water fish, fish meal and other processed feedstuffs. Food and Agriculture Organization of the United Nations Fish Circular No. 856. Rome: FAO.

Tacon, A. and Jackson, A. (1985). Protein sources in fish feeds. In Cowey, C.B., Nackie, A.M. and Bell, J.G. (Eds). Nutrition and Feeding in Fish, p. 120 - 145. London, United Kingdom: Academic Press.

Tacon, A. and Metian, M. (2008). Global overview on the use of fish meal and fish oil in industrially compounded aquafeeds: Trends and future prospects. Aquaculture, 285(1-4), 146-158. https:// doi.org/10.1016/j.aquaculture.2008.08.015

Terpstra, A.H. (2015). Feeding and growth parameters of the tilapia (Oreochromis niloticus). An overview of data from the literature and the internet. Retrieved from website: http://www.tilapiastichting.nl/ Downloads/3\%20-\%20AHM\%20Terpstra\%20-\% 202015\%20-\%20Feeding\%20and\%20Growth\% 20Parameters $\% 20 \mathrm{of} \% 20$ the $\% 20$ Tilapia.pdf

Watanabe, T. (2002). Strategies for further development of aquatic feeds. Fisheries Science, 68(Suppl. 1), 101 $-104$. https://doi.org/10.1046/j.14442906.2002.00418.x

Yunita, M.A., Sudarno and Manan, A. (2019). Addition of organic waste on nile tilapia (Orechromis niloticus) commercial fish feeding. International Journal of Civil Engineering and Technology, 10(5), 373-379.

Zar, J. (1996). Bio Statistical Analysis. 3rd ed., p. 662. New Jersey, USA: Prentice-Hall.

Zerai, D., Fitzsimmons, K., Collier, R. and Duff, G. (2008). evaluation of brewer's waste as partial replacement of fish meal protein in nile tilapia, Oreochromis niloticus, diets. Journal of the World
Aquaculture Society, 39, 556-564. https:// doi.org/10.1111/j.1749-7345.2008.00186.x 